\title{
Foreign Direct Investment (FDI) and Policy Inconsistence in Nigeria (1970-2016)
}

\author{
M. Y. Kabara ${ }^{1}$ and K. Amirthalingam ${ }^{2}$ \\ ${ }^{1}$ Faculty of Graduate Studies, University of Colombo \\ ${ }^{2}$ Department of Economics, Faculty of Arts, University of Colombo
}

\begin{abstract}
Foreign Direct Investment is the dominant and the most reliable source of deficit financing to nations mostly developing and third world characterized with low investible fund since early 80s. This is against the backdrop that investible funds generated from high saving are a necessary condition for economic growth. However, the all-encompassing determinant of FDI is the consistency in the economic policy especially in the third world and developing economies like Nigeria. It is against this that this study seeks to measure the effect of policy inconsistency on the flow of FDI in Nigeria from 1970 to 2016 using Annual and Cumulative Growth Rate approach. The study revealed that policy inconsistency within the period reviewed has a serious impact on the flow of FDI. In line with this, it was part of the recommendations that Nigerian governments at all levels should reduce the rate of policy change and volatility through the design and pursuance of long term economic and FDI related policies with a strong legislation that they must remain uninterrupted even with a change of political leadership.
\end{abstract}

Keywords: Investment, Multinational cooperation, policy inconsistence

\section{Introduction}

The macroeconomic environment of Nigeria is for long characterized with high volatility like those of most developing economies. The volatility of the Nigerian economy since early $70^{\text {th }}$ was caused by the successive dwindling fortunes of the economy as a result of the fallen market demand of oil which provides Nigeria with more than $80 \%$ of its revenue and $90 \%$ of foreign exchange earnings (Biodun, 2004).

However, at the global arena, it has been acknowledged that in the last two decades or so International trade and capital movement across borders stands the dominant and fastest economic activity across the length and the breadth 
of the global village (UNCTAD, 2008). This development is further explained by the gradual and significant increase in Foreign Direct Investment (FDI) flow at the global level since the decline of the official lending sources such as grants and aids to the developing economies.

Despite the dramatic success of FDI at the global stage, Africa as a developing continent throughout the 1990s could not claim more than $2 \%$ of the global FDI. Over 1980-1989 and 1990-1998, for example, FDI to Sub Saharan Africa (SSA) grew by 59\%. This is compared with an increase of 5,200\% for Europe and Central Asia, 942\% for east Asia and Pacific, 740\% for South Asia, 455\% for Latin America and Caribbean and 672\% for all developing countries (World Bank, 2000 a).

Policy reforms as may be preferred by political class and the economic policy managers could easily degenerate into policy inconsistency which signifies the random flow of the former term. It is quite unequivocal that reforms are sought to provide a critical and supportive platform for reorientation and reposition of existing status quo in order to attain an effective and efficient state (Ajayi, 2005). But when such reforms become illogical and bias to non-continuity of the hitherto existing policies, they could be termed inconsistent and often yielded undesirable outcome. This assertion could be supported by a more radical definition of reforms by Obadan (2006) who posits that reforms are deliberate actions by the government to fast track, jump start and consolidate specified sectors of the economy to achieve a desired objective.

A stable and transparent policy framework towards FDI is one very influential consideration of Multinational Corporations and foreign investors in deciding where to invest or not to. In fact, this determinant is labeled as the bed rock upon which all other determinants are laid. Without a certain and consistent policy framework the remaining determinants even when provided could not attract the desired level of investment. This is because foreign investors prefer any arrangement that will support long run adjustments for better return (Schinieder and Frey, 1995; and Langhammer, 1991).

Policy uncertainty/inconsistency in Nigeria is a function of mainly the incessant changes in governments, military and civilian, that characterized 
the polity since the political independence of 1960. This is why the study assumed that policy uncertainty is synonymous to incessant changes in governments and their policies. In essence, political leadership which refers to the ruling class that bears the responsibility of managing the affairs and the resources of the political entity by setting and influencing policy priorities affecting the territory through different decision-making structures and institutions created for the orderly development of the territory as defined by Micheal, (2012) has been the fulcrum of the rampant changes of economic policies in Nigeria. By a priori expectation, policy uncertainty is likely to affect FDI negatively.

The policy inconsistencies were largely attributed to the political instability as manifested in the rampant and incessant changes in government. From the Nigeria's independence of 1960 to date the country has witnessed 15 different regimes both military and democratic. Some changes in the political leadership were muted with bloodshed and wanton killings. This in no small measure discourages the flow and activities of foreign direct investors especially during the military junta characterized with little or no regard to the rule of law. It is against this, that policies inconsistencies are alternatively measured by the policy dynamisms manifested in oscillatory behavior of FDI flow within the period under review as a result of changes in political leadership.

Most of the studies on FDI in Nigeria were observed to be concentrating on examining the effect of economic determinants like market size, openness of the economy, available natural resource, and infrastructure, interest rate and macroeconomic stability. Others were political risk, national assets, domestic credits, legal system, population health and governance (Eugena, 2010, Omowomi, 2014). The studies have succeeded in coming up with various findings and suggestions on the supposed determinants of FDI in Nigeria but yet the share of the foreign direct investment into Nigeria is still very low. Hence the need to conduct a more critical examination of some of those FDI determinants and those that were neglected in the recent literature such as policy inconsistency.

The objective of this study is to discuss how inconsistencies in economic policies formulation and execution affects and influences the flow of foreign direct investment into Nigeria within the period under review. The study also 
sets to examine the effects of policy inconsistency on the pre deregulated and post deregulated regimes in Nigeria $(1970$ - 1986 and 1986 - 2016 respectively). To achieve this, the researchers use annual secondary and published time series data obtainable from Statistical Bulletin of the Central Bank of Nigeria CBN on Foreign Direct Investment (FDI) for descriptive analyses. The article is organized in phases that include after the introduction, Literature review and the theoretical background, methodology of the study, data analysis and result discussions and recommendation.

\section{Literature Review}

Foreign Direct Investment determinants are country specific and of various classifications. According to Farnandez-Arias 1996; Fernandez-Arias and Montein 1996; Gottscalk, 2001; FDI determinants can be viewed as either push factor determinants or pull factor determinants depending on their analytical directions. Push factors involved determinants such as cyclical and the structural conditions of a nation while pull factors were explicitly such like economic, socio-political conditions including uncertainties. Pull or domestic factors are within the control of the host country; hence endogenous to host country and exogenous to the home country.

In another classifications, FDI determinants can still be polarized into two i.e. policy determinants and non-policy determinants. The policy determinants are but not limited to market openness, product market regulations, labor market, corporate tax rate, FDI restrictions, trade barriers and infrastructure. Non-policy drivers of FDI on the other hand involved market size of host country often measured in GDP terms, distance/transport cost, population, factor endowment, political and economic stability (Mateev, 2009).

Sekket and Veganzones-Varoudakis (2007) have chosen to group determinants of FDI inflows into three categories: basic economic factors, trade and exchange market policies and investment climate factors. The first category involves the difference in the rate of returns on capital across countries, portfolio diversification strategy of the investors and market size of the host country. Trade and foreign exchange policies considerations relate to trade liberalization, exchange rate movement and their volatility 

(1970-2016)

(Front and Stein, 1991). Business climate factors are infrastructural (Wheeler and Modey, 1992). Labor cost and availability of skilled labor/education, incentive factors, political risk, economic factors (per capita GDP, GDP growth rate, economic integration, transport, commerce and communication). Social factors such as the degree of urbanization and political stability like number of constitutional changes in government (Roat and Ahmed 1979; Schineider and Frey 1985).

In a study carried out by Anitha (2012), on foreign direct investment and economic growth in India, emphasis was laid mostly in improving the modern understanding of FDI roles in developing countries. The study revealed that lack of the needed level of income, saving and investment which are crucial in financing development is the major push for FDI. In other words, FDI plays the role of bridging the saving-investment gap in countries of the world especially the developing and the third world. By extension, Anitha (2012), using India as a case study which is today one of the fastest growing economies since her adoption of the openness/deregulation policy in 1991, revealed empirically that FDI enhances competiveness of domestic economy by ensuring backward linkage with the domestic industries in the long run through transfer of technology, strengthening socioeconomic infrastructure, raising productivity and generating new employment opportunities. The study which adopted the use of Autoregressive Integrated Moving Average (ARIMA) technique in projecting and forecasting FDI inflow generated for a period of five years (2010-1014/15) also revealed that the open policy of India through Liberalizing and Globalizing results into a massive foreign investment mobilization, mostly from western countries and America.

To support the assertion that the benefits of FDI are best observable in the long run rather than in the short run especially when effect of the lagged investment is very low, a very interesting study was carried out by Gladson (1986). The study was on "The impact of the foreign direct investment on domestic capital formation in developing country: Nigeria", using a time series data from 1960-1980. Like said earlier in this study distinction was made between the short run and long run effects of foreign investment on domestic capital. The study revealed that FDI has a displeasing impact on domestic capital formation in the short run as per every 1 of inflow of FDI 
leads to 2.90 decline on the domestic investment. This was attributed to the positive effect of FDI on increased consumption of imported products. However, on the long run, the impact of FDI on the domestic investment was reported to be positive as $\$ 1$ of FDI inflow leads to additional $\$ 3.7$ which was perceived to be resulting from the positive multiplier effect on invested fund. Gladson (1986) strongly disagrees with those FDI critiques that see it as destructive. Without dismissing the possibilities of economic disadvantages of FDI he opined that it is and will continue to be an important source of long run growth capital to developing economies including Nigeria.

However, Benassy-Quere et al (2001), simply put the effect of exchange rate on FDI as ambiguous. However, inflation which is the widely accepted proxy for economic instability, by a priori expectation, is of negative effect to FDI. In other words, high inflationary trend in the host country discourages foreign investment (Nnadozi and Osili 2004). But in some studies, inflation tends to yield positive impact on FDI (Brahmasrene and Jiranyakul 2001). This view suggested a situation whereby the inflation is cost push i.e. as a result of increase in the prices of input materials to the local producers who are highly volatile to internally unguarded policies. But it may not affect the foreign investors in a similar magnitude who are protected and provided with incentives, equipment and raw materials importation subsidies. This will make the MNCs products cheaper in the host country than those produced by the local investors. This, as FDI critiques opined, instigates the dearth of the local infant industries which gives a bad signal to the growth and survival of the local economy.

\section{Methodology and Model Specification}

The study as ex post facto mainly chooses to use Annual Secondary and Published Time Series data obtainable from Statistical Bulletin of the Central Bank of Nigeria CBN on Foreign Direct Investment (FDI), as dependent variable which will be modelled with the policy changes in Nigeria as the independent variable from 1970 - 2016. To measure the effect of the independent variable on the dependent Annual Growth Rate (AGR), Compounded Annual Growth Rate (CAGR) through Descriptive Analysis will be used. This will reveal the number of major structural breaks the Nigerian economy witnessed as a result of policy dynamism within the 

(1970-2016)

period under review. The study will discuss the genesis of such dynamisms and shocks using available literature on the nature, history and the structure of Nigerian economy from 1970 to 2015. All monetary values in the analysis will be measured in Naira term ( $)$ which is the official currency of Nigeria. This will facilitate the better understanding of the research findings.

The variable of policy inconsistency which is thought to be best measured using the Annual Growth Rate (AGR) and Compounded Annual Growth Rate (CAGR) approach as highlighted above is adopted from the work of Anitha (2012) titled "Foreign direct investment and economic growth in India" when measuring the effect of policy change in India's pre liberalization and post liberalization regimes. Anitha's work was published in International Journal of Marketing, Financial Services and Management Research.

Annual Growth Rate and the Compounded Annual Growth Rate will provide in quantitative terms the change in investment flow into Nigeria per annum in response to the possible changes in FDI related policies and at the compounded level of the years under review which is $1970-2016$ respectively. The value at the end of the computation will be provided in percentage hence the effect of the changes in policies on the flow will be interpreted in percentage as well. In this regard, a distinct equation is specified for "Policy Inconsistency" variable as follows:-

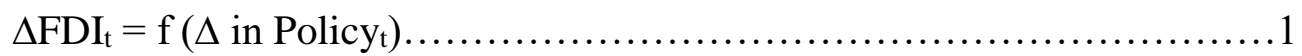

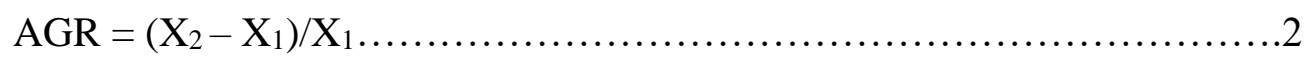

Where:

$\Delta \mathrm{FDI}_{\mathrm{t}}=$ Numerical change in the flow of Foreign Direct Investment annually

$\Delta$ In Policy $_{\mathrm{t}}=$ This is the rate at which policies are changed annually. This denotes the rate at which the government changes FDI policies and programmes and how such lead to the change in economic growth within the period under review. This could be captured by the changes in the Growth Domestic Product (GDP) as a proxy to economic growth over the years.

AGR $=$ This denotes the Annual Growth Rate. It measures the percentage change in growth rate over a period of one year. It is the summation of the AGR that leads to the Compounded Annual Growth Rate (CAGR), which is used to compute the cumulative change in economic growth over the years. 
$\mathrm{X}_{1}=$ First value of the variable $\mathrm{X}$

$\mathrm{X}_{2}=$ Second Value of the variable $\mathrm{X}$ and

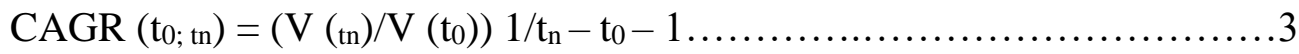

Where $\mathrm{V}\left(\mathrm{t}_{0}\right)=$ Start value

$\mathrm{V}(\mathrm{tn})=$ Finish value and

$\mathrm{tn}_{-} \mathrm{t}_{0}=$ Number of years

The a priori expectation is the $\Delta$ in policy affects negatively the $\Delta$ in FDI in Nigeria $(1970-2016)$.

In modeling this relationship, however, we must reiterate that the economic policy inconsistency in Nigeria is yet a function of the incessant and incoherent changes in political leadership legitimately or otherwise. It is not out of place to mention that the mantle of leadership in Nigeria from her political independence of $1^{\text {st }}$ October, 1960 to date, changed hands seventeen (17) times. This technically indicated that there is averagely a change of political leadership in Nigeria after every 3.5 years. This may suggest the direction of the a priori expectation against the dependent variable FDI which is negative.

\section{Findings and Discussion}

FDI as a long run phenomenon requires policies and government action plans that would survive the test of time. This will afford the investors enough time to maximize the expected long run economy of scale benefits. It is against this, and the available literature on how economic policies and their changes within the period under review affect FDI in Nigeria, most studies reported a very sad picture of the relationship.

This is because prior to the commencement of the explicit deregulation regime in July 1986 when the most radical effort was made through the introduction of the famous Structural Adjustment Programme (SAP), Nigeria as an economic entity was largely cherishing protective policies with a motive of shielding the local investors and their investments against the vagaries of the foreign investors. The government at that time believed that exposing them (infant industries) to the cut throat competitive atmosphere with the rival multinational corporations will do more harm than good to the domestic economy. In fact the dogma which is typical of countries at the earlier stage of their independence was manifested in the Nigerian Enterprise 

(1970-2016)

Promotion Decree (NEPD) of 1972, and other anti-foreign investment policies as well as action plans that were borne out of the so called sense of economic nationalism.

Another reason that could explain a very low FDI flow from 1970 - 1985 as shown in the appendix 2 was the then global economic crises of the early $80 \mathrm{~s}$ in the face of largely closed economy, except in those investments openings where special expertise that could not be sourced locally is needed e.g. the oil industry which was the main stay of the economy since early 70 s. The gloomy picture was also supported by the cumbersome and bureaucratic requirements in business registration. Fortunately, this was taken care of by the Industrial Development Coordination Act (ICDA) which brought a lot of relief to prospective and the already existing foreign investors. However, just after a while the policy was replaced with a stringent one that subjected those investors that were lulled by the first Act (ICDA) into a serious economic dilemma. In what looks like a total policy reversal, a new policy under Companies and Allied Matters Act (CAMA) was totally set to discourage the inflow of FDI into Nigeria. The policy insisted that no foreign owned company will be allowed to operate in Nigeria unless it was initially incorporated in the country as a separate entity. The only set of companies exonerated in that policy act were those owned by foreign governments, those invited by the Nigerian government itself and those executing loan projects and supervised by the international donor organizations like IMF as well as companies executing technical projects.

Foreign direct investors could not respond immediately to the Nigerian deregulation policy of 1986 which came after the suspension of the National Development Plans (Four Fixed Medium Term Plans of 1962 - 1968, 1970 1974, 1975 - 1980 and 1981 - 1985). This was largely informed by the bitter lesson they learnt from the previous successive anti-investment policies such as the Indigenization and Nationalization policies and other obnoxious fiscal and monetary action plans that were not friendly. Having noticed this slow response, the government commences the privatization policy in 1988 which was already encapsulated in 1986 SAP policy prescriptions. The policy was presented in the Nigerian Privatization and Commercialization Decree of 1988. One of the main thrusts of the policy was to enable the foreign investors to acquire an ownership of just up to $40 \%$ of the shares of the 
government privatized companies for the flow of capital and management expertise that were envisaged to be the bane of the collapse of most public enterprises in Nigeria. The Decree provided that the remaining $60 \%$ will be shared between the Nigerian government and the local investors at $40 \%$ and $20 \%$ respectively. This arrangement sounds too bias to attract FDI. These put together explain the flat and stiff movement on the graph (appendix 2) from 1995 through 1991.

However, the rise in the FDI inflows from 1995 onward could be attributed to the abolishing of all foreign ownership restrictions as imposed by the Foreign Exchange Act of 1962 and the Nigerian Enterprise Promotion Decree of 1962 and their replacement with the Nigerian Investment Promotion Commission Decree of 1995. However, the reason why despite this total abolishing of the two earlier non FDI friendly policies discussed above, a very sharp increase in FDI flow into Nigeria could not be achieved as the above graph shows was the fact that the government still maintains the joint venture arrangements with foreign multinationals operating in oil and gas industries which were also the largest destination of FDI in Nigeria.

Nevertheless, this indicated that the FDI activities started increasing around 1992 when the 1986 SAP could be assumed to have moved into long run stage despite its embodied problems. Another reason that could explain this was a sudden policy reversal that limits access to Forex. Up till 1994, as spelt under the Second Tier Foreign Exchange Market Act (SFEM Act) buying and selling of foreign currencies from or to Nigerians by foreigners was free with lesser requirements. This provides a leverage that guarantees the access to Forex. In what looks like a policy transgression, by 1994, this monetary regime was also suspended in an abrupt manner and replaced with Monetary, Credit and Foreign Exchange/Trade guidelines that largely discouraged the activities of foreign investors in Nigeria. In addition to this, the policy came with the following stringent tightening measures.

- Pegging the local currency at 22 to a dollar for all transactions.

- Foreign exchange is made available to importers through bidding supervised by CBN.

- No business will be allowed into Nigeria with declaration of less than $\$ 5000$. 
- Bureau de change are no longer allowed to sell foreign currencies in exchange for Nigerian currency as was the case since 1989 when they were created and licensed by government.

Despite the strategic importance of forex policies in determining the flow of FDI, Nigeria was observed to have conflicting foreign exchange regimes and incessant reversals (Lloyd, 2005) that could be instrumental in explaining the above graph. By 1962 to 1973, that was immediately after independence, in furtherance of her anti-investment policies Nigeria was in her Fixed Exchange Rate era which was followed by;

- Dual Exchange Rate System era 1986

- Unified Exchange Rate System 1987

- Inter-bank Foreign Exchange Market 1989

- Completely Deregulated Exchange Rate System 1992

- Re-introduction of the Fixed Exchange Rate System 1994 (Reversal)

- Dual Exchange Rate Regime 1995 (Reversal)

After observing some problems with SAP that was initially expected to yield results in not later than three years from its inception, the government decided to re-introduce those fixed medium term plans as National Rolling Plans in 1990, partly with a view to increasing and accelerating FDI flow into Nigeria by strengthening the base for market-oriented economy among other objectives. Unfortunately, these rolling plans were largely accused of achieving little than expected and rolled over by 2003 for the introduction of National Economic Empowerment and Development Strategy (NEEDS) which is yet another policy package thought to accelerate economic growth through increased deregulation and provision of FDI friendly atmosphere. An improvement was recorded over the previous periods mainly in the inflation targets and increase in the national savings. However, the package was discredited in maintaining a low capital formation which reflects that the high savings recorded could not be translated into savings. However, in line with this, NEEDS was replaced with Vision 20:2020 framework of development in 2010. The frame aspired to enroll Nigeria among the first 20 economies of the world by the year 2020, through privatization, deregulation 
and openness of the Nigerian economy. Like majority of the economic indicators such as non-oil GDP, global ranking of the country, inflation, market capitalization, FDI also performed impressively during the period of 2011-2012.

It is in relation to the above analytical description of the graph (appendix 2) that the Compounded Annual Growth Rate of Foreign Direct Investment is computed and reported to be 0.15 i.e. $0.15(15 \%)$. This indicated that the growth rate of FDI within the years under review was just 15\%. This is caused largely by the influence of anti-foreign investment policies implemented in the pre deregulate regime spanning from 1970 to 1986 and, secondly, the inconsistencies of the macroeconomic FDI related policies even after the deregulation as discussed above as well as other factors such as the preponderance of social unrests and wars.

\section{Recommendations}

To reduce the rate of policy volatility and inconsistency, government needs to henceforth be designing long term economic policies backed with sincere legislation that they must remain unaltered even with the change of political leadership. This will largely alleviate the fears of the existing and prospective investors.

The Nigerian government should propose policies that will enhance the effectiveness of the Nigerian market size so that apart from having a positive effect on the FDI flow it will also be significant. This could be achieved by improving the purchasing power of average Nigerians by making available private sector employment openings. It is important to state that until the private sector is empowered to be the major driver of the Nigerian economy a sizeable proportion of Nigerians will remain either unemployed or underemployed with very little income for effective demands, and this will continue to make the market size big but hollow. In essence, the government should ensure a market of effective demand.

Governments at all levels are to stop the occurrence and reoccurrence of the habitual civil and political crises that remained a serious impediment to the economic survival of Nigeria since her independence. It is very important to note that these crises milked Nigeria dry by shying away sizeable number of 
foreign and local investors to the neighboring countries. This recommendation is important since it could be achieved by ensuring internal security that will give the foreign investors the confidence to move around with their resources without a fear of being robbed, killed or kidnapped. In addition to this, Nigeria must continue to join hands with the neighboring countries in ensuring a regional peace and security.

\section{Conclusion}

It is pertinent to understand that International Economics/Investment as a broader field of study that essentially discusses the flow of human and material resources across borders. This transfer of resources could be in the form of indirect investment (portfolio investment) or direct investment with the former just a passive means of venturing into an international economic/business relation. Prior to 1950 there was no any explicit concept of FDI. Discussions on FDI were covered under the study of portfolio investment that explains capital flow across borders as determined by only the interest rate in the host country.

The movement of capital investment is basically in three forms. Foreign Direct Investment (FDI) consists of investments into a country by foreign nationals and controlling over $10 \%$ of the equity shares. This enables the foreign investor or multinational corporations to have an active voice in the control and management of the business. Secondly, indirect investment as otherwise called portfolio investment is the form of ownership in which the foreign investor has no voice in the management of the investment unless otherwise is explicitly stated in the business agreement and lastly, official loans indicate the flow of finances in the form of loans from foreign banks/ countries to another. This form of flow of investible capital is discouraged since the global economic distress of 1980s.

Generally speaking, however, the investment activities of multinational corporations which are the major shippers of foreign direct investment could be discussed in three different ways i.e. horizontal FDI, vertical FDI and export platform FDI. Each of these varieties explains a different investment scenario which recognizes the set target of the multinational corporation in question. 
In this study, however, policy inconsistency as a cardinal determinant of FDI is reported to be instrumental in discouraging the flow of the resource into Nigeria within the period reviewed. This did not come with a surprise considering the extent of policy volatility in Nigerian context where different governments come with different economic and FDI related policies. This is reported under findings and discussions and recommendations were built there from.

\section{References}

Ajayi, M. (2005). "Banking sector reforms and bank consolidation: Conceptual framework". CBN Bullion, 29(2): 12-40.

Anitha, R. (2012). "Foreign direct investment and economic growth in India", International Journal of Marketing, Financial Services and Management Research, 1(8): 108-125

Benassy-Quere, A., Lionel, F. and Lahreche-Revil A. (2001). "Exchange rate stratagies in the competition for attracting foreign direct investment", Journal of the Japanese and International Economics, 15(2): 178198.

Biodun, A. (2004). "The impact of oil on Nigeria's economic policy formulation", Conference on Nigeria Maximizing Pro poor Growth: Regenerating the Socio Economic Data Base", Organized by Oversea Development Institute in collaboration with Nigerian Economic Summit Group, $16^{\text {th }}-17^{\text {th }}$, June, 2004.

Brahmasrene, T. and Jiranyakul K. (2001). "Foreign direct investment in Thailand: What factors matter?" Proceeding of the Academy for International Business, 1(2): 13-14

Dunning, J.H. (2004). "Institutional reform, FDI and European transition economies" International Business and Government in the $21^{\text {st }}$ Century, Cambridge University Press, 1-34, www.reading.ac.uk. 
(1970-2016)

Eugena, M. (2014). "Determinants of foreign direct investment in Nigeria: Evidence from Co-integration and Error Correction Model", International Journal of Business and Social Sciences. 5, $6^{\text {th }}$ May 2014.

Fernandez-Arias, E, and Montiel, P. (1996). "The surge in capital inflows to developing countries: An analytical overview", The World Bank Economic Review, 10(1): 51-77.

Fernandez-Arias, E. (1996). "The new wave of capital inflows: Push or Full?" Journal of Development Economics, 48: 389-418.

Gladson, I. N. (1986). "Impact of foreign direct investment and domestic capital for developing country: Nigeria", Savings and Development, 10(3): $265-278$.

Gottschalk, R. (2001). 'Lenders' and investors' international portfolio allocation decisions: what do we know?" Institute of Development Studies, Sussex.

Langhammer, R. (1991). "Competition among developing countries for foreign investment in the eighties - whom did OECD investors prefer?" Welwirtschaftliches Archiv, 127: 390-403.

Lloyd, A.A. and Tokumbo, S.O. (2005). "Determinants of the choice of the exchange rate regimes in Nigeria", Pakistan Economic and Social Review, Vol. 43, No. 1, (summer, 2005), pp. 71 - 92, Published by Department of Economics, University of the Punjab.

Mateev, M. (2009). "Determinants of foreign direct investment in Central and South Eastern Europe: New empirical test", Oxford Journal, 8(1): 133-149.

Michael, M. O. (2012). "Political leadership and corruption in Nigeria since 1960: A Socio economic analysis", Journal of Nigeria Studies, 1(2):1-25. 
Nnadozi, E. and Osili, V.O. (2004). "US foreign direct investment in Africa and its determinants", UNECA Workshop of Financial System and Mobilization in Africa, Nov. $2^{\text {nd }} 2004$.

Obadan, M. I. (2006). "Globalization of finance and the challenges of national financial sector development". In: A Adeola, O Olanrenwagu (Eds.): Applied Macroeconomics and Economic Development. Ibadan: University Press, pp. 132-158.

Obadan MI 2006 Globalization of finance and the challenges of national financial sector development, Journal of Asian Economics, 17(2): 316-332

Omowumi, O.I. and Abel, A.A. (2014). "Foreign Direct Investment in Nigeria", International Journal of Liberal Arts and Social Sciences, 2(9): 71-87

Roat, F.R. Ahmed, V. and Ahmed, A. (1979) "Empirical determinants of manufacturing direct foreign investment in developing countries", Economic Development and Cultural Change, 27(4): 751-767.

Schineider, F. and Frey, B.S. (1995). "Economic and political determinants of foreign direct investment", World Development, 13(2), 161-175.

Sekkat, K. and Veganzones-Varoudakis, M.A. (2007). "Openness, investment climate and FDI in developing countries", Review of Development Economics, 11(4), 607-620.

UNCTAD, (2003). World Investment Report Trends and Determinants, New York and Geneva; United Nations.

Wheeler, D. \& Mody, A. (1992). International investment location decision: the case of US firms. Journal of International Economics, 33, 57-76.

World Bank Report, (WBR, 2000). 

(1970-2016)

\section{Appendix One}

VOLUME OF FDI INFLOWS INTO NIGERIA FROM 1970 - 2016 in Millions

\begin{tabular}{|c|c|c|}
\hline Years & FDI & $\operatorname{AGR}(\%)$ \\
\hline 1970 & $1,003.20$ & \\
\hline 1971 & $1,322.80$ & 0.328581 \\
\hline 1972 & $1,571.10$ & 0.187708 \\
\hline 1973 & $1,763.70$ & 0.122589 \\
\hline 1974 & $1,812.10$ & 0.027442 \\
\hline 1975 & $2,287.50$ & 0.262348 \\
\hline 1976 & $2,339.00$ & 0.022514 \\
\hline 1977 & $2,531.40$ & 0.082257 \\
\hline 1978 & $2,863.20$ & 0.131074 \\
\hline 1979 & 3.153 .10 & 0.10125 \\
\hline 1980 & $3,620.10$ & 0.148108 \\
\hline 1981 & $3,757.90$ & 0.038065 \\
\hline 1982 & $5,382.80$ & 0.432396 \\
\hline 1983 & $5,949.50$ & 0.10528 \\
\hline 1984 & $6,418.30$ & 0.078797 \\
\hline 1985 & $6,804.00$ & 0.060094 \\
\hline 1986 & $9,313.60$ & 0.368842 \\
\hline 1987 & $9,993.60$ & 0.073012 \\
\hline 1988 & $11,339.20$ & 0.134646 \\
\hline 1989 & $10,899.60$ & -0.03877 \\
\hline 1990 & $10,436.10$ & -0.04252 \\
\hline 1991 & $12,243.50$ & 0.173187 \\
\hline 1992 & $20,512.70$ & 0.675395 \\
\hline 1993 & $66,787.00$ & 2.255885 \\
\hline 1994 & $70,714.60$ & 0.058808 \\
\hline 1995 & $119,391.60$ & 0.688359 \\
\hline 1996 & $122,600.90$ & 0.02688 \\
\hline 1997 & $128,311.80$ & 0.046744 \\
\hline 1998 & $152,409.60$ & 0.187621 \\
\hline 1999 & $154,188.60$ & 0.011672 \\
\hline 2000 & $157,535.40$ & 0.021706 \\
\hline 2001 & $162,343.40$ & 0.03052 \\
\hline 2002 & $166,631.60$ & 0.026414 \\
\hline 2003 & $178,478.00$ & 0.071093 \\
\hline 2004 & $249,220.60$ & 0.396366 \\
\hline 2005 & $269,844.70$ & 0.082754 \\
\hline 2006 & $302,843.30$ & 0.122287 \\
\hline 2007 & $364,008.50$ & 0.20197 \\
\hline 2008 & $397,395.20$ & 0.09172 \\
\hline
\end{tabular}


2009

2010

2011

2012

2013

2014

2015

2016

$1970-2016$
$1,237,800.00$

$905,700.00$

$1,360,300.00$

$1,113,500.00$

$875,100.00$

$738,200.00$

$602,100.00$

$592,100.00$
2.114783

$-0.2683$

0.501932

$-0.18143$

$-0.2141$

$-0.15644$

$-0.18437$

$-0.11900$

SOURCE: 2015/2016 issues of CBN Statistical Bulletins and computed by the researcher

\section{Appendix Two}

FDI INFLOWS FROM 1970 - 2016

FDI

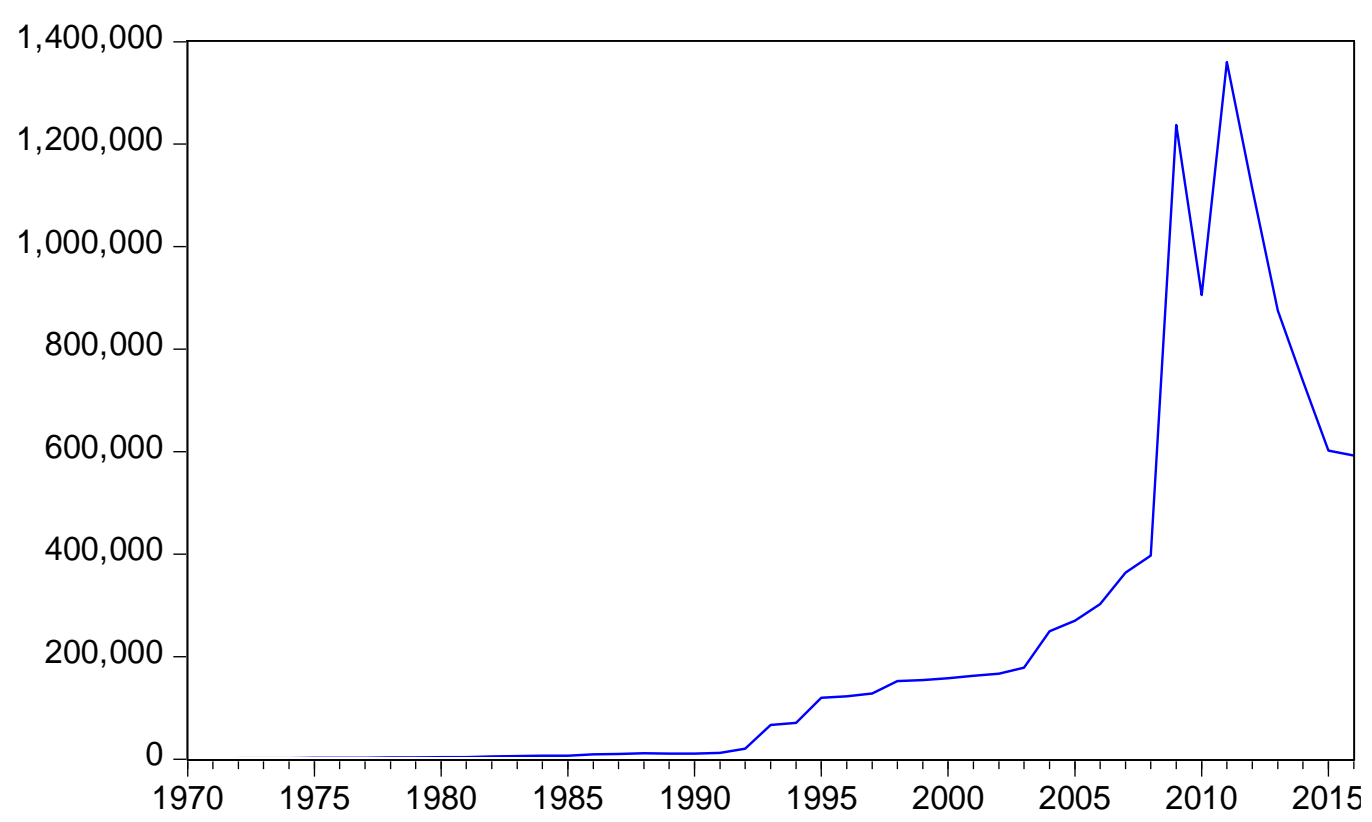

SOURCE: Data from 2016/2017 CBN Statistical Bulletins and computed by the researcher 